\title{
Do we need to wait? Does reducing time to prostate MRI postbiopsy interfere with staging?
}

\author{
J Rowlands \\ From International Cancer Imaging Society Meeting and 15th Annual Teaching Course (ICIS 2015) \\ London, UK. 5-7 October 2015
}

\begin{abstract}
Aims
With an MRI scanner at the limit of capacity (and no immediate prospect of an additional scanner) we are unable to offer pre biopsy MRI due to the workload expansion - further 24 slots/ month. We aimed to evaluate if reducing the time between biopsy and scan led to a decrease in staging accuracy due to post biopsy haemorrhage.
\end{abstract}

\section{Methods}

Retrospective study comparing haemorrhagic artefact and staging accuracy in MRI studies performed before and after a pathway change reduced the time to MRI post biopsy.

\section{Results}

No difference in rate of post biopsy haemorrhage deemed to affect diagnostic accuracy.

No significant staging error in either group.

Reduced time to discussion on MDT led to improvement in treatment time and no RTT (Referral To Treatment) pathway breaches.

Pathway improved by 8.65 days ( $14 \%$ of RTT time).

\section{Conclusion}

In a capacity limited service there is no option to go to prebiopsy service with the increase in demand that would ensue. It is reassuring to know that reducing the time between biopsy and scan results in no difference in number of studies affected by haemorrhage, no difference in diagnostic accuracy and leads to improvement in patient treatment pathway.

Published: 2 October 2015

Correspondence: jennifer.rowlands@sath.nhs.uk

The Shrewsbury and Telford NHS Trust, UK
doi:10.1186/1470-7330-15-S1-P46

Cite this article as: Rowlands: Do we need to wait? Does reducing time to prostate MRI postbiopsy interfere with staging? Cancer Imaging 2015 15(Suppl 1):P46.
Submit your next manuscript to BioMed Central and take full advantage of:

- Convenient online submission

- Thorough peer review

- No space constraints or color figure charges

- Immediate publication on acceptance

- Inclusion in PubMed, CAS, Scopus and Google Scholar

- Research which is freely available for redistribution
C Biomed Central

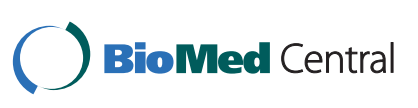

(c) 2015 Rowlands This is an Open Access article distributed under the terms of the Creative Commons Attribution License (http:// creativecommons.org/licenses/by/4.0), which permits unrestricted use, distribution, and reproduction in any medium, provided the original work is properly cited. The Creative Commons Public Domain Dedication waiver (http://creativecommons.org/publicdomain/ zero/1.0/) applies to the data made available in this article, unless otherwise stated. 